\title{
Correction to: Role of Dominant Phyllosphere Bacteria with Plant Growth-Promoting Characteristics on Growth and Nutrition of Maize (Zea mays L.)
}

\author{
Vahid Alah Jahandideh Mahjen Abadi ${ }^{1} \cdot$ Mozhgan Sepehri $^{1}$ (1) $\cdot$ Hadi Asadi Rahmani ${ }^{2} \cdot$ Mehdi Zarei $^{1}$. \\ Abdolmajid Ronaghi ${ }^{1}$ - Seyed Mohsen Taghavi ${ }^{3} \cdot$ Mahdieh Shamshiripour $^{2}$
}

Published online: 21 July 2021

(c) Sociedad Chilena de la Ciencia del Suelo 2021

\section{Correction to: Journal of Soil Science and Plant Nutrition (2020) 20:2348-2363} https://doi.org/10.1007/s42729-020-00302-1

The authors acknowledge that part of the results presented in this article ${ }^{1}$ (Fig 3 and Table 1) were previously published in the Electronic Journal of Soil Management and Sustainable Production ${ }^{2}$. These are preliminary, laboratory results that were included in this article ${ }^{1}$ to support the discussion on additional, greenhouse results which are original and the main focus of the article published in the Journal of Soil Science and Plant Nutrition.

\section{References:}

Abadi, V.A.J.M., Sepehri, M., Rahmani, H.A. et al. Role of Dominant Phyllosphere Bacteria with Plant GrowthPromoting Characteristics on Growth and Nutrition of
Maize (Zea mays L.). J Soil Sci Plant Nutr 20, 2348-2363 (2020). https://doi.org/10.1007/s42729-020-00302-1 Abadi V.A.J.M, Sepehri M, Rahmani H.A et al Isolation and identification of maize phyllosphere bacteria and determination of their plant growth promoting traits. J. of Soil Management and Sustainable Production 10:2 (2020). https://doi.org/10.22069/ejsms.2020.17475.1921

Publisher's note Springer Nature remains neutral with regard to jurisdictional claims in published maps and institutional affiliations.

The original article can be found online at https://doi.org/10.1007/ s42729-020-00302-1

Mozhgan Sepehri

m.sepehri@shirazu.ac.ir

1 Department of Soil Science, School of Agriculture, Shiraz University, Shiraz, Iran

2 Agriculture Research, Education and Extension Organization, Soil and Water Research Institute, Karaj, Iran

3 Department of Plant Protection, School of Agriculture, Shiraz University, Shiraz, Iran 